Key Words:

Tritiated water

Bremsstrahlung

Liquid Scintillation

Retention:

Permanent

\title{
FINAL REPORT FOR TRITIUM WATER MONITOR
}

\author{
R. A. Sigg \\ D. P. DiPrete \\ B. A. Ferguson
}

APRIL 25, 2011

Savannah River National Laboratory Savannah River Nuclear Solutions, LLC Aiken, SC 29808

Prepared for the U.S. Department of Energy under contract number DE-AC09-8SR22470.

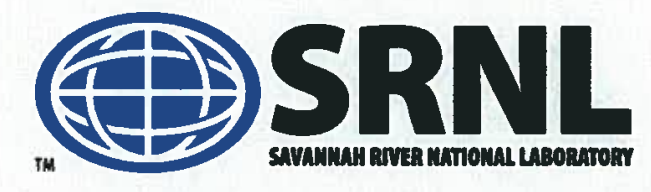




\section{DISCLAIMER}

This work was prepared under an agreement with and funded by the U.S. Government. Neither the U.S. Government or its employees, nor any of its contractors, subcontractors or their employees, makes any express or implied:

1. warranty or assumes any legal liability for the accuracy, completeness, or for the use or results of such use of any information, product, or process disclosed; or

2. representation that such use or results of such use would not infringe privately owned rights; or

3. endorsement or recommendation of any specifically identified commercial product, process, or service.

Any views and opinions of authors expressed in this work do not necessarily state or reflect those of the United States Government, or its contractors, or subcontractors.

\section{Printed in the United States of America}

Prepared for

U.S. Department of Energy 
Key Words:

Tritiated water

Bremsstrahlung

Liquid Scintillation

Retention:

Permanent

\title{
FINAL REPORT FOR TRITIUM WATER MONITOR
}

\author{
R. A. Sigg \\ D. P. DiPrete \\ B. A. Ferguson
}

APRIL 25, 2011

Savannah River National Laboratory Savannah River Nuclear Solutions, LLC Aiken, SC 29808

Prepared for the U.S. Department of Energy under contract number DE-AC09-8SR22470.

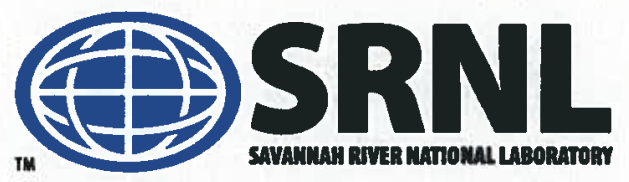




\section{ACKNOWLEDGEMENTS}

The authors would like to recognize the contributions of Dr. Leah M. Arrigo and Donald J. Pak for their contribution toward the completion of this project. 


\section{EXECUTIVE SUMMARY}

The objective of this Plant Directed Research \& Demonstration (PDRD) task was to develop a system to safely analyze tritium in moisture collected from glovebox atmospheres in the Savannah River Site (SRS) Tritium Facility. In order to minimize potential radiation exposures that could occur in handling and diluting high-tritium-content water, SRS sought alternatives to liquid-scintillation counting. The proposed system determines tritium concentrations by measuring Bremsstrahlung radiation induced by low-energy beta interactions in liquid samples. Results show that, after a short counting period (30 seconds), detection limits are three orders of magnitude below the described concentration of tritiated water in the zeolite beds. Additionally, this report covers the analysis of process samples and the investigation of several cell window materials including beryllium, aluminum, and copper. Final tests reveal that alternate window materials and thicknesses can be used to obtain useful results. In particular, a window of stainless steel of moderate thickness $(0.3$ $\mathrm{cm}$ ) can be used for counting relatively high levels of tritium. 


\section{TABLE OF CONTENTS}

ACKNOWLEDGEMENTS

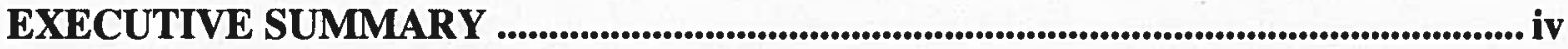

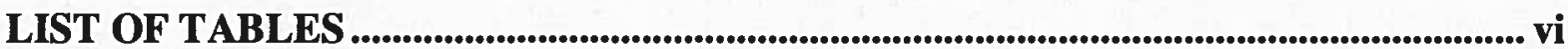

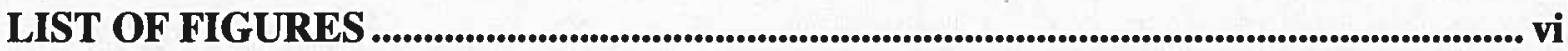

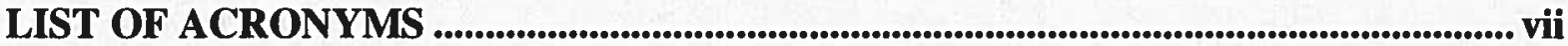

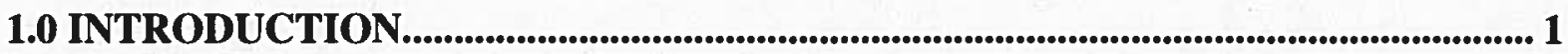

2.0 EXPERIMENT

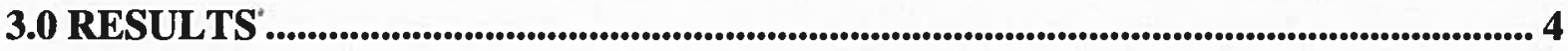

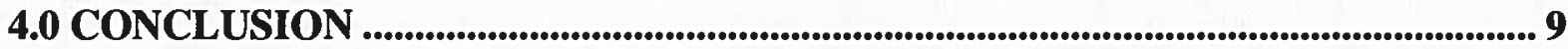

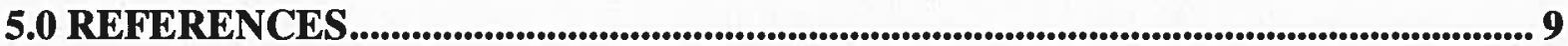




\section{LIST OF TABLES}

Table 1. The tritium concentration in the sample received and for the diluted material used in this study. SRNL tracked the material under LIMS number 300252085...... 3

Table 2. Absorber material areal densities and thicknesses used to evaluate tritium Bremsstrahlung attenuation....................................................................................................... 3

Table 3. Minimum detectable activity (MDA) of tritium by Bremsstrahlung radiation of diluted process sample $(0.121 \mathrm{Ci} / \mathrm{mL})$.

\section{LIST OF FIGURES}

Figure 1. Plastic cell for counting Bremsstrahlung from tritiated water samples. 2

Figure 2. Calibration of the $\mathrm{NaI}$ detector. $\mathrm{L} X$-rays and the $59.5 \mathrm{keV}$ gamma ray from ${ }^{241} \mathrm{Am}$, and the $\mathrm{K} \mathrm{X}$-rays from ${ }^{137} \mathrm{Cs}$.

Figure 3. Changes in tritium Bremsstrahlung spectra for increasing thicknesses of beryllium absorbers. .........................................................................................5 5

Figure 4. Relative changes in tritium Bremsstrahlung count rates using beryllium

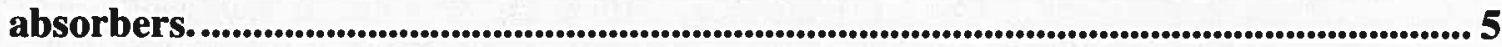

Figure 5. Changes in tritium Bremsstrahlung spectra for increasing thicknesses of aluminum absorbers. .....................................................................................6 6

Figure 6. Changes in tritium Bremsstrahlung count rates using aluminum absorbers. . 7 Figure 7. Changes in tritium Bremsstrahlung spectra for increasing thicknesses of copper absorbers. .....................................................................................................8 8

Figure 8. Changes in combined tritium Bremsstrahlung and copper $X$-ray count rates using increasing thicknesses of copper absorbers. 


\section{LIST OF ACRONYMS}
AD
Analytical Development
LIMS
Laboratory Information Management System
MDA
Minimum Detectable Activity
PDRD
Plant Directed Research \& Demonstration
RTF
Replacement Tritium Facility
SRS
Savannah River Site
SRNL
Savannah River National Laboratory 


\subsection{INTRODUCTION}

The Replacement Tritium Facility (RTF) located at the Savannah River Site (SRS) currently processes tritium for national defense purposes. Some tritium is "lost" as tritiated water in the processing gloveboxes. Currently, the "lost" tritium is captured and recovered through collection on zeolite beds. The water in the zeolite beds contain from 10 to 2000 atomic parts per million (appm) tritium. This recovery process costs approximately $\$ 70,000$ per magnesium bed processed, not including labor costs. Recent estimates show that for approximately $90 \%$ of the tritium recovery operations, it would be more cost effective to directly dispose of the tritiated water than to recover the tritium. The ability to determine in advance whether the bed should be recovered would save considerable cost and facilitate direct disposal of the tritium-contaminated water. Plant Directed Research \& Development (PDRD) testing, completed in 2007, determined that Bremsstrahlung radiation measurements were a viable option for measuring on-line samples of tritiated water using a thin-window sodium iodide ( $\mathrm{NaI}$ ) scintillation detector.

Implementing an appropriate on-line technology for tritium analysis would help the Tritium Facility meet a recognized need, achieve significant annual cost savings, and avoid unnecessary personnel exposures and environmental contamination. The ability to measure Bremsstrahlung radiation from tritiated water using a thin-window $\mathrm{NaI}$ scintillation detector has been demonstrated. ${ }^{1,2}$ The results show that excellent statistical precision can be obtained in relatively short counting periods even when the tritium concentration levels are much lower than those of interest to the facility. Such analysis results could guide whether the material contains sufficient tritium for economical recovery, or whether it should be stabilized for disposal as waste.

Facility personnel expressed concern with using the originally-designed Bremsstrahlung counting cell in a pressurized process line. Additionally, tritium compatibility with plastic (hydrocarbon) windows was of concern. For potential use in pressurized systems, a part of this study evaluated changes in count rates for various thicknesses of absorber windows. Since low-energy Bremsstrahlung photons are easily attenuated, the tests used available sets of beryllium ( $\mathrm{Be})$, aluminum $(\mathrm{Al})$ and copper $(\mathrm{Cu}$, to simulate stainless steel) to look at a diluted process water sample that was collected from the Tritium Facility's glovebox air stripper system; each set included a range of material thicknesses. Because the sample's activity was much higher than the $\sim 60 \mu \mathrm{Ci} / \mathrm{mL}$ material that was available for the earlier work, the sample provided realistic counting statistics for testing thicker and higher $\mathrm{Z}$ materials than the beryllium used previously.

\subsection{EXPERIMENT}

The experimental setup in this report has previously been described. ${ }^{1,2}$ The stainless steel cell used in FY2007 was modified and machined of polypropylene for FY2008 work (as seen in Fig. 1); it has an internal volume of $4.7 \mathrm{~mL}$ and a $25.4 \mathrm{~mm}$ diameter window (plastic cell). The window of the cell was constructed from Dupont Delrin (polyoxymethylene). 


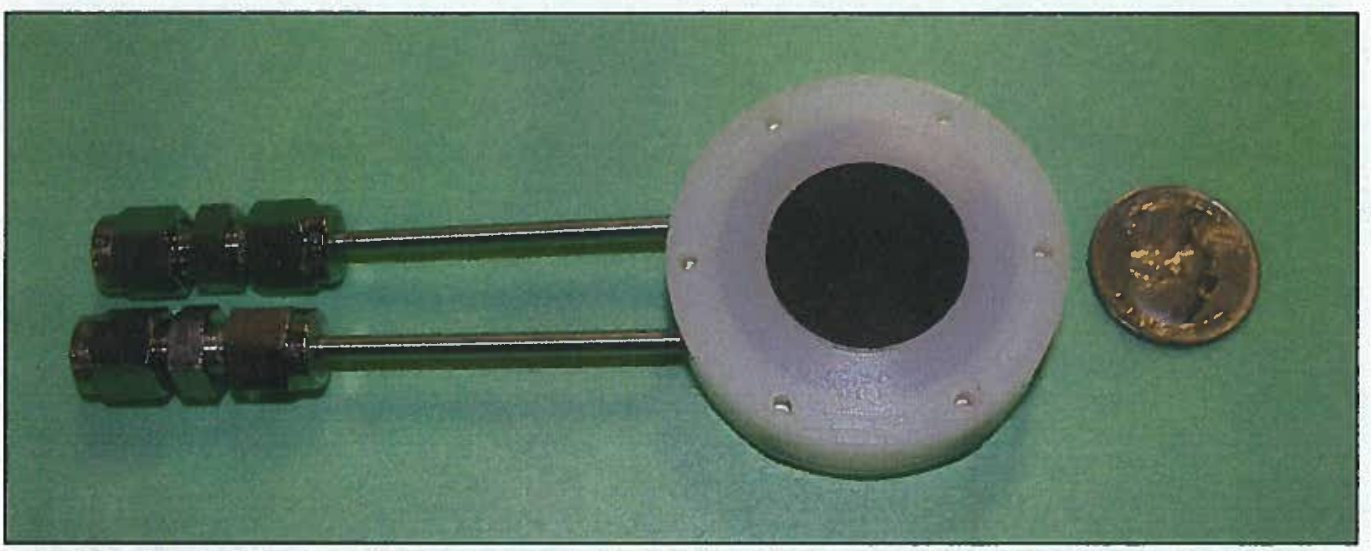

Figure 1. Plastic cell for counting Bremsstrahlung from tritiated water samples.

Previously, Bremsstrahlung spectrometry data were collected with Low Energy Germanium and NaI detectors for $50,000 \mathrm{sec}$ using a $2.5 \times 10^{6} \mathrm{Bg} / \mathrm{mL}$ (or $6.76 \times 10^{-5} \mathrm{Ci} / \mathrm{mL}$ ) HTO solution contained in the stainless steel tritiated water cell. ${ }^{1,2}$ The count rate was low $(0.18 \mathrm{CPS})$ as compared to water removed from the RTF zeolite beds, and thus the zeolite sample required significantly shorter counting times. The NaI detector was energy calibrated using L X-rays $(17.8 \mathrm{keV})$ and the $59.5 \mathrm{keV}$ gamma ray from ${ }^{241} \mathrm{Am}$ decay, and the $\mathrm{K} \mathrm{X}$-rays $(32 \mathrm{keV})$ of ${ }^{137}$ Cs decay (Fig. 2).

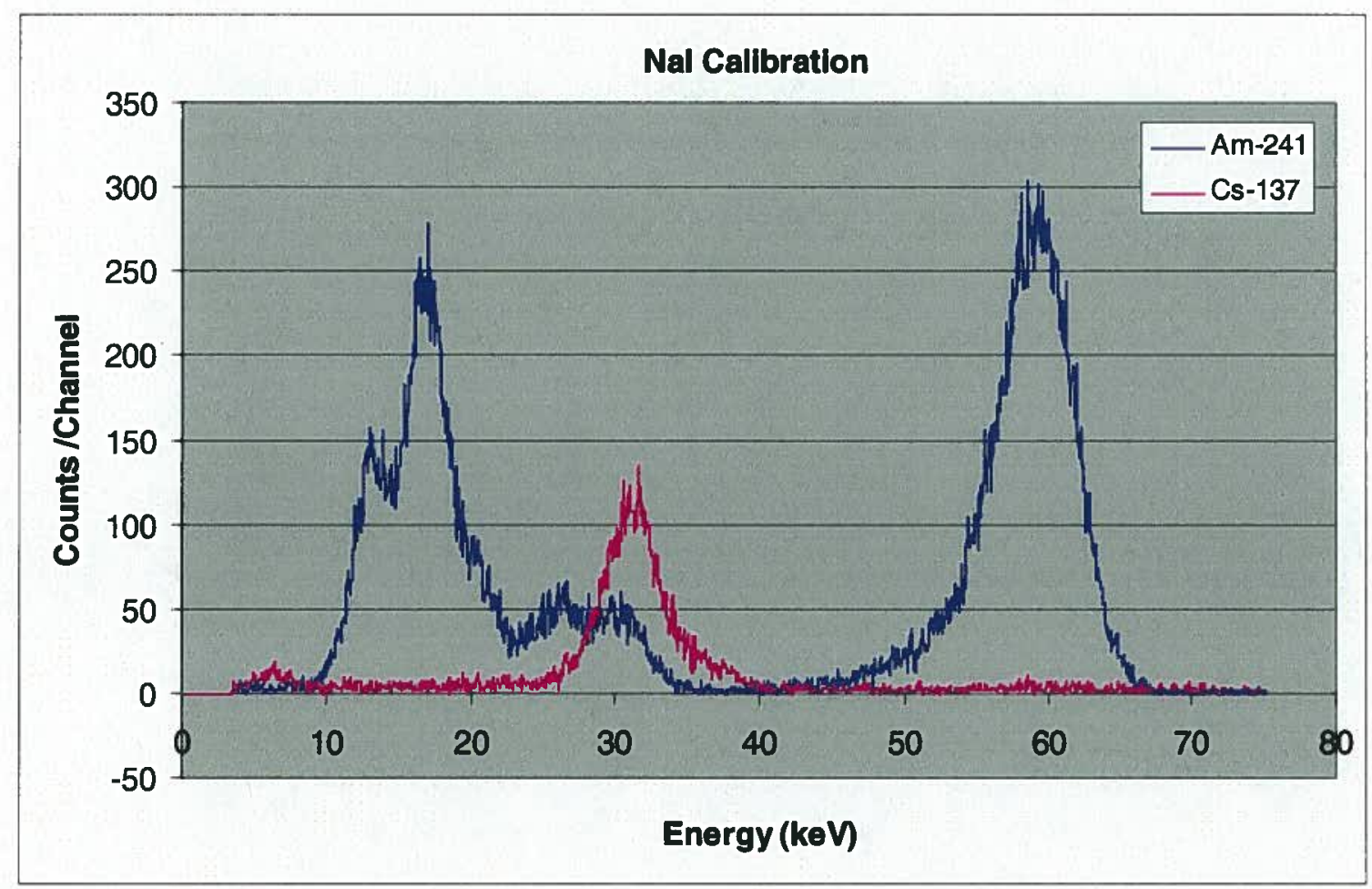

Figure 2. Calibration of the NaI detector. L X-rays and the $59.5 \mathrm{keV}$ gamma ray from ${ }^{241} \mathrm{Am}$, and the K X-rays from ${ }^{137} \mathrm{Cs}$. 
Zeolite water sample: In 2008, a water sample was analyzed by SRNL from the Tritium Facility H-Area New Manufacturing (HANM) Z-Bed Recovery System and was found to contain tritium, nitrite, nitrate, ammonium, sulfur, copper, and nickel. ${ }^{3}$ The water sample was recovered between the Normetex and ZR-B2 Met-Bel pumps, as well as after the MetBel pump (pumps which pull the gas through the $\mathrm{Mg}$ bed). Water was also found in various places from the $\mathrm{Mg}$ bed to the recovery bed inlet. A plastic pipette was used to transfer the water to a sample vial for submission to SRNL Analytical Development for analysis. ${ }^{4}$ Analytical Development personnel analyzed the sample in the condition it was received from the facility in September 2008 using liquid scintillations (results are listed in Table 1). The activity was found to be $1.21 \mathrm{Ci} / \mathrm{mL}$. Small deionized water dilutions were made for analysis by the Bremsstrahlung sensor system.

Table 1. The tritium concentration in the sample received and for the diluted material used in this study. SRNL tracked the material under LIMS number 300252085.

\begin{tabular}{|c|c|}
\hline Sample ID & Tritium Activity $(\mathrm{Ci} / \mathrm{mL})$ \\
\hline Z Bed Liquid, July 08 & 1.21 \\
10X Diluted Sample & 0.121 \\
\hline
\end{tabular}

Comparison of alternative window materials: The $10 \mathrm{X}$ diluted tritium water sample $(0.121 \mathrm{Ci} / \mathrm{mL})$ was placed into the described plastic sample cell and was used to collect spectra for various materials and absorber thicknesses. The absorbers were placed between the counting cell and a thin-window NaI scintillation detector. The NaI detector was used to optimize performance for low energy photons such as those from tritium Bremsstrahlung. It had a $0.025 \mathrm{~cm}$-thick beryllium window for low-energy photon transmission. Table 2 described the absorber materials used and corresponding areal density and thicknesses.

Table 2. Absorber material areal densities and thicknesses used to evaluate tritium Bremsstrahlung attenuation.

\begin{tabular}{|c|c|c|c|c|c|}
\hline \multicolumn{2}{|c|}{ Be } & \multicolumn{2}{c|}{ Al } & \multicolumn{2}{c|}{ Cu } \\
\hline $\mathrm{mg} / \mathrm{cm}^{2}$ & $\mathrm{~cm}$ & $\mathrm{mg} / \mathrm{cm}^{2}$ & $\mathrm{~cm}$ & $\mathrm{mg} / \mathrm{cm}^{2}$ & $\mathrm{~cm}$ \\
\hline 0 & 0.000 & 0 & 0.000 & 0 & 0.000 \\
37.5 & 0.020 & 225 & 0.083 & 624 & 0.070 \\
68.0 & 0.037 & 370 & 0.137 & 1060 & 0.118 \\
86.8 & 0.047 & 370 & 0.137 & 1860 & 0.208 \\
137 & 0.074 & 593 & 0.220 & 2920 & 0.326 \\
356 & 0.192 & 870 & 0.322 & & \\
491 & 0.265 & 1075 & 0.398 & & \\
886 & 0.479 & 2450 & 0.907 & & \\
& & 3540 & 1.311 & & \\
& & 4250 & 1.574 & & \\
& & 8950 & 3.315 & & \\
\hline
\end{tabular}




\subsection{RESULTS}

\section{Polyoxymethylene Absorber Results}

Using the plastic cell with a Delrin window (polyoxymethylene), a minimum detectable activity (MDA) of tritium by Bremsstrahlung radiation was calculated (Table 3 ). The MDA calculations were made using a background count rate integrated from 0 to $20 \mathrm{keV}$, the activity of the diluted process sample, the volume of the cell, and the count rate with the cell in contact with the face of the NaI detector.

Table 3. Minimum detectable activity (MDA) of tritium by Bremsstrahlung radiation of diluted process sample $(0.121 \mathrm{Ci} / \mathrm{mL})$.

\begin{tabular}{|c|c|c|}
\hline Count-Time (min) & MDA $(\boldsymbol{\mu} \mathbf{C} \mathbf{i})$ & MDA (appm) \\
\hline 0.5 & 1116.8 & 0.0240 \\
1.0 & 789.7 & 0.0170 \\
1.5 & 644.8 & 0.0139 \\
2.0 & 558.4 & 0.0120 \\
3.0 & 455.9 & 0.0098 \\
4.0 & 394.9 & 0.0085 \\
5.0 & 353.2 & 0.0076 \\
10.0 & 249.7 & 0.0054 \\
15.0 & 203.9 & 0.0044 \\
\hline
\end{tabular}

Counting durations varied from 30 seconds to 15 minutes, and the MDAs ranged from around $1 \times 10^{-2}$ to $1 \times 10^{-3}$ appm over this range of counting times. Even though the efficiency was very low (due to low Bremsstrahlung production), the MDAs were much better than those available from mass spectroscopy and much better than the range of interest to the facility, where the concentration of tritium ranges from 100 to several thousand appm. There was room for modifications to meet facility implementation needs and desires. The MDA calculations were used only as rough guidance for what MDAs might be in the facility. This was because the final cell design, the window material and thickness, the actual counting geometry, and the facility background were all likely to be different from those used in these scoping measurements.

Due to time constraints, the beryllium windowed cell was not utilized for a direct comparison. The process data showed that thicker Be or other window materials could be used to address facility concerns.

\section{Beryllium Absorber Results}

As stated earlier, beryllium absorbers of varying thickness, were placed between the counting cell and a NaI scintillation detector. Fig. 3 shows spectra collected with no absorber and with increasing thicknesses of beryllium, and Fig. 4 plots relative changes in counts versus absorber thickness. Each spectrum was collected for 120 seconds with a detector-tocounting-cell spacing of about one centimeter. 


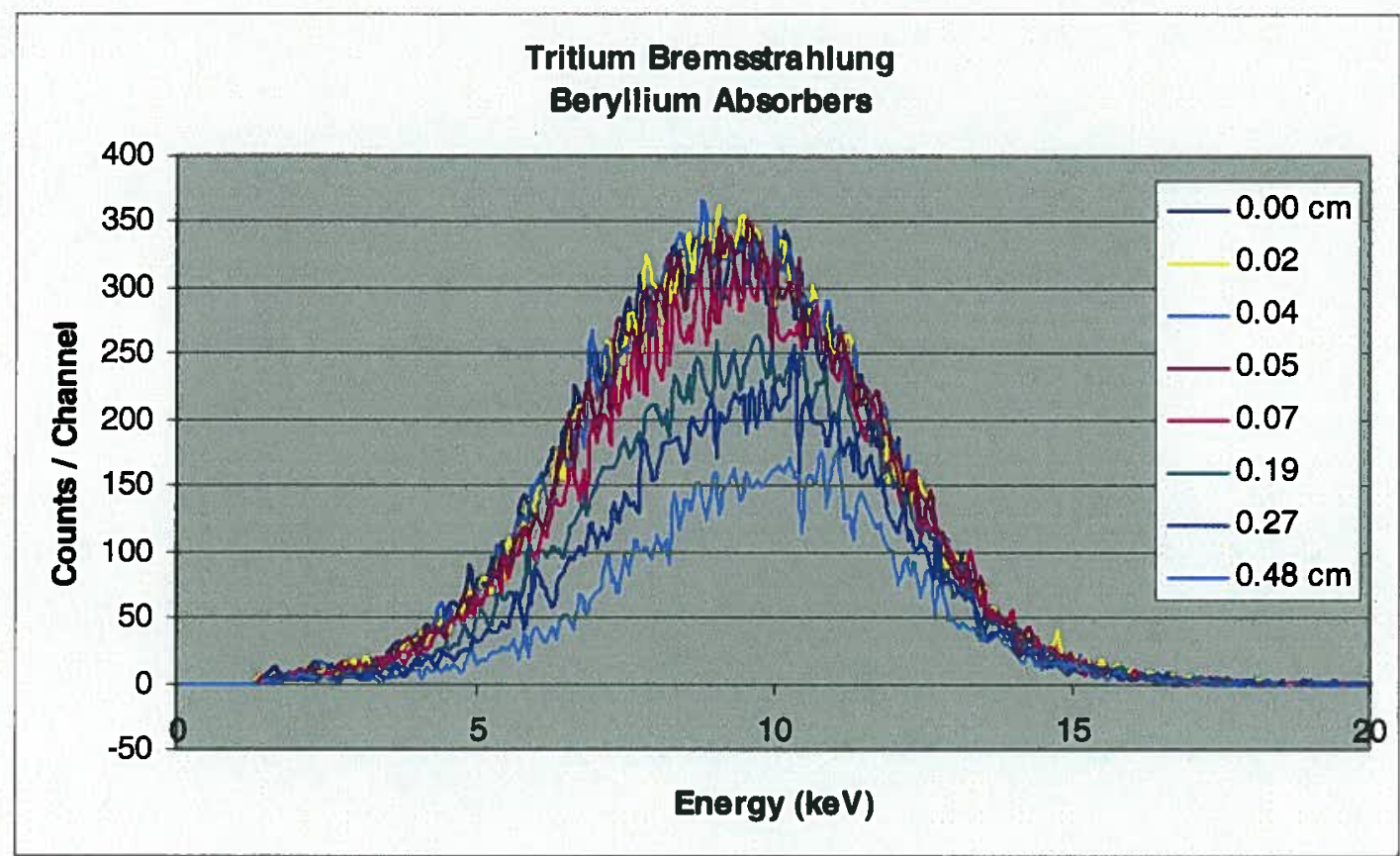

Figure 3. Changes in tritium Bremsstrahlung spectra for increasing thicknesses of beryllium absorbers.

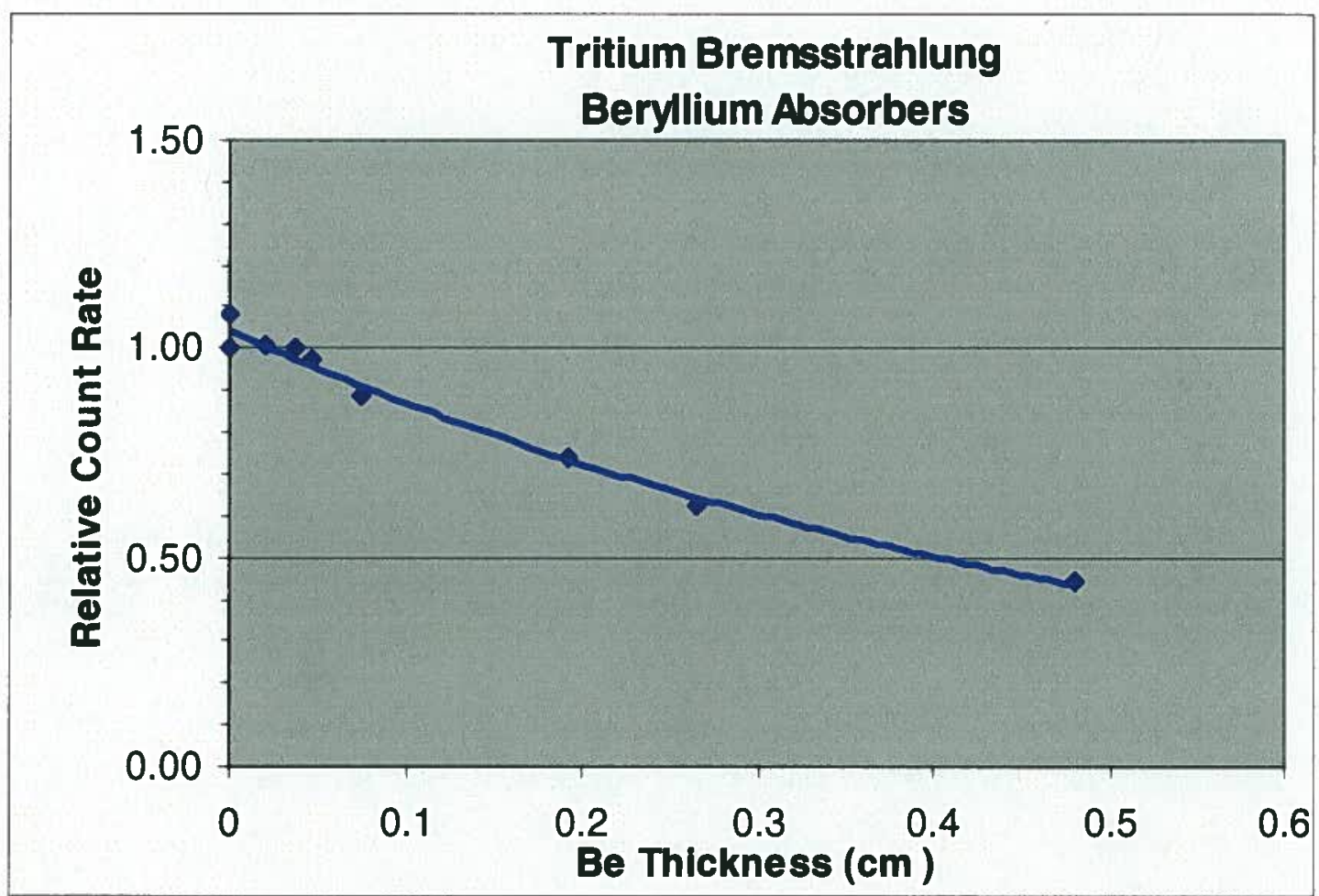

Figure 4. Relative changes in tritium Bremsstrahlung count rates using beryllium absorbers. 
Only about half of the signals were lost using Be absorbers up to $\sim 0.5 \mathrm{~cm}$ thick, which was still in the range desired by the Tritium Facility. Note that the distribution shifted to higher energies as the absorber thickness increased; this was due to selective absorption of lower energy photons. Similar results were seen in the aluminum absorber data, but not in the data for copper absorbers. This will be discussed further in later sections.

\section{Aluminum Absorber Results}

In order to evaluate the possible use of other window materials that would transmit lowenergy tritium Bremsstrahlung radiation, a set of aluminum absorbers was used. Though aluminum probably would not be used for the counting cell window in the facility, the data are useful for showing the effects of increasing material density $\left(2.7 \mathrm{~g} / \mathrm{cm}^{3}\right)$ and atomic number (13) relative to those for beryllium $\left(1.86 \mathrm{~g} / \mathrm{cm}^{3}\right.$ and 4 respectively). Changes in tritium Bremsstrahlung spectra and changes in count rates as a function of aluminum absorber thickness are shown in Fig. 5 and 6, respectively.

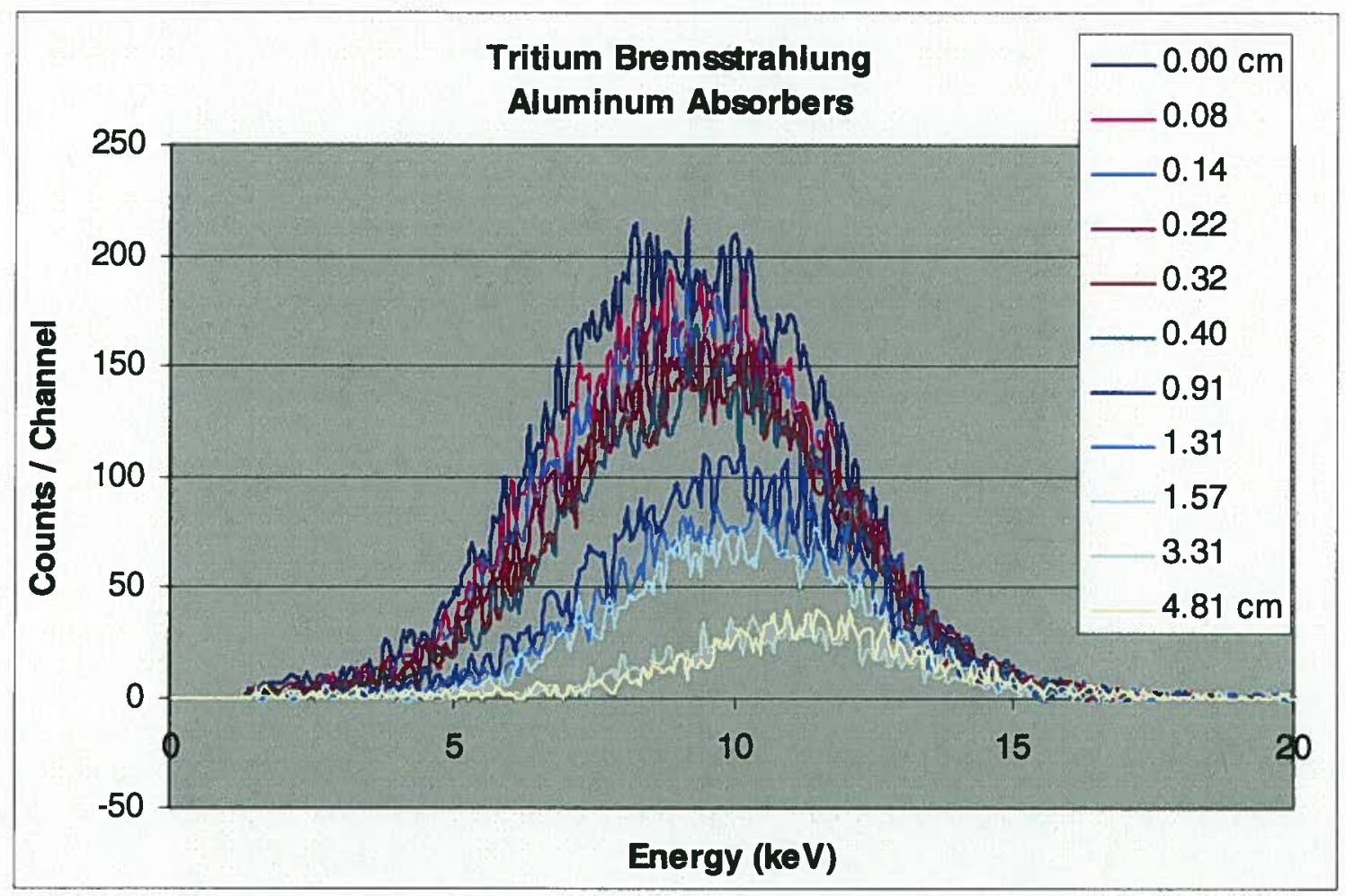

Figure 5. Changes in tritium Bremsstrahlung spectra for increasing thicknesses of aluminum absorbers. 


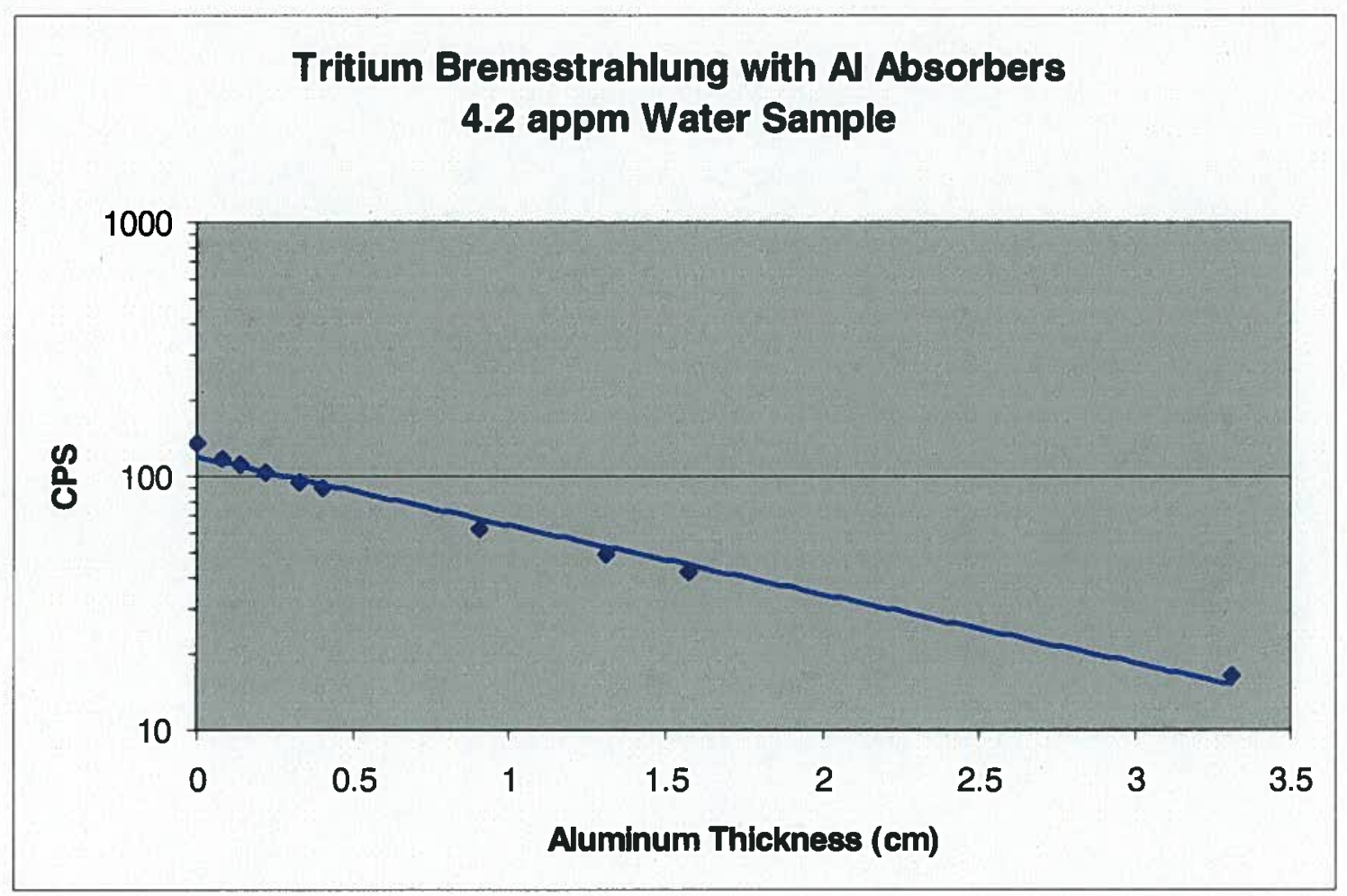

Figure 6. Changes in tritium Bremsstrahlung count rates using aluminum absorbers.

As seen earlier with the beryllium absorber material, as the thickness of the aluminum absorber material increased, there was a decrease in the low-energy photon response and a peak shift to a higher energy was observed.

\section{Copper Absorber Results}

The absorber set utilized during this study did not include stainless steel. Since the atomic number of copper is 29 and the atomic number of iron is 26 , the data provides a reasonable approximation of the attenuation expected to be caused if stainless steel were used as a window. The density of copper is also slightly higher than that of iron and stainless steel, and provides a conservative estimate for the behavior of a stainless steel window.

Changes in shapes of the spectra were observed as the copper thickness increased (Fig. 7). The broad Bremsstrahlung component rapidly decreased in intensity and shifted to higher energies as the copper thickness increased (Fig. 8); however, an additional feature was seen at lower energies due to production of copper fluorescent $\mathrm{X}$-rays. 


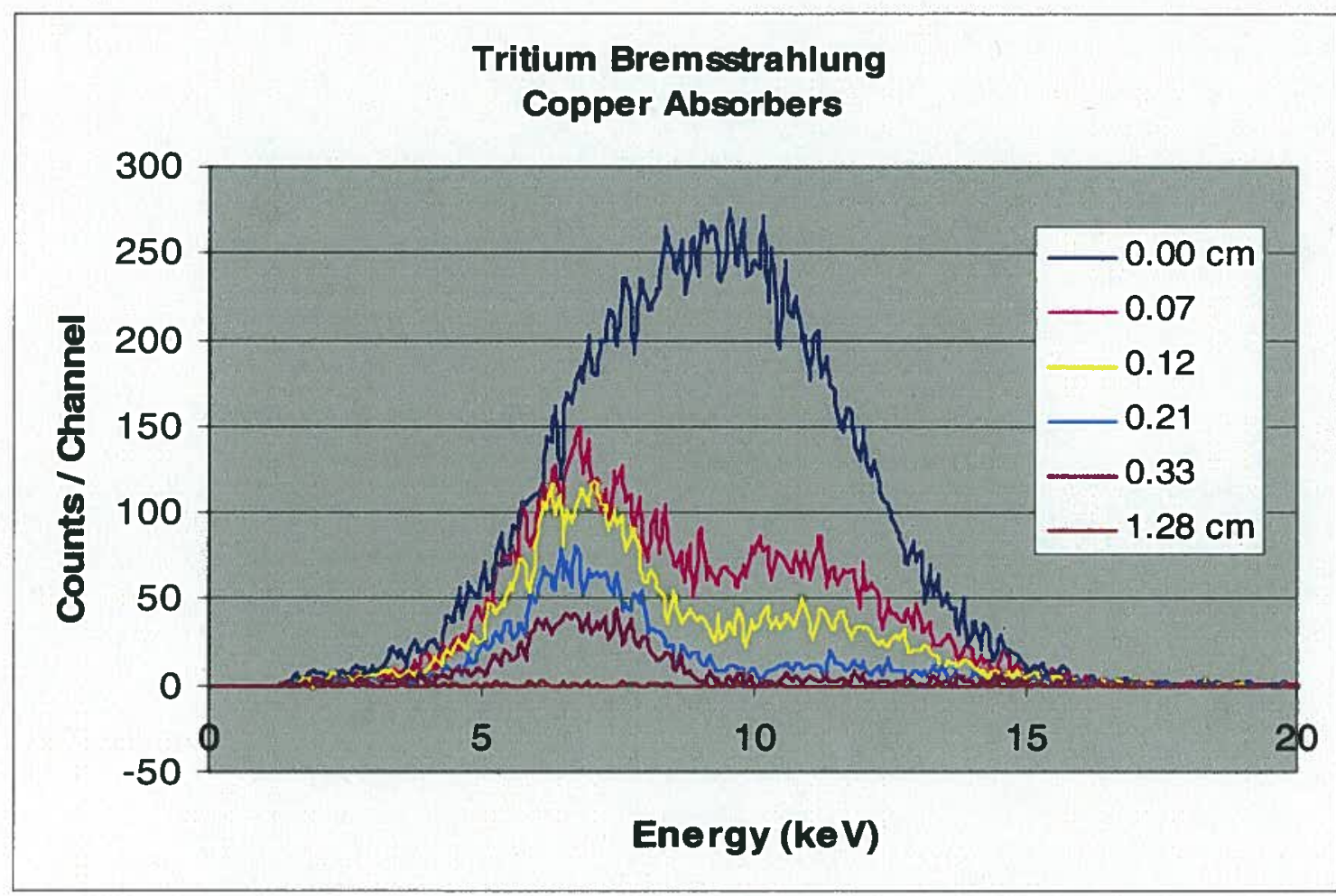

Figure 7. Changes in tritium Bremsstrahlung spectra for increasing thicknesses of copper absorbers.

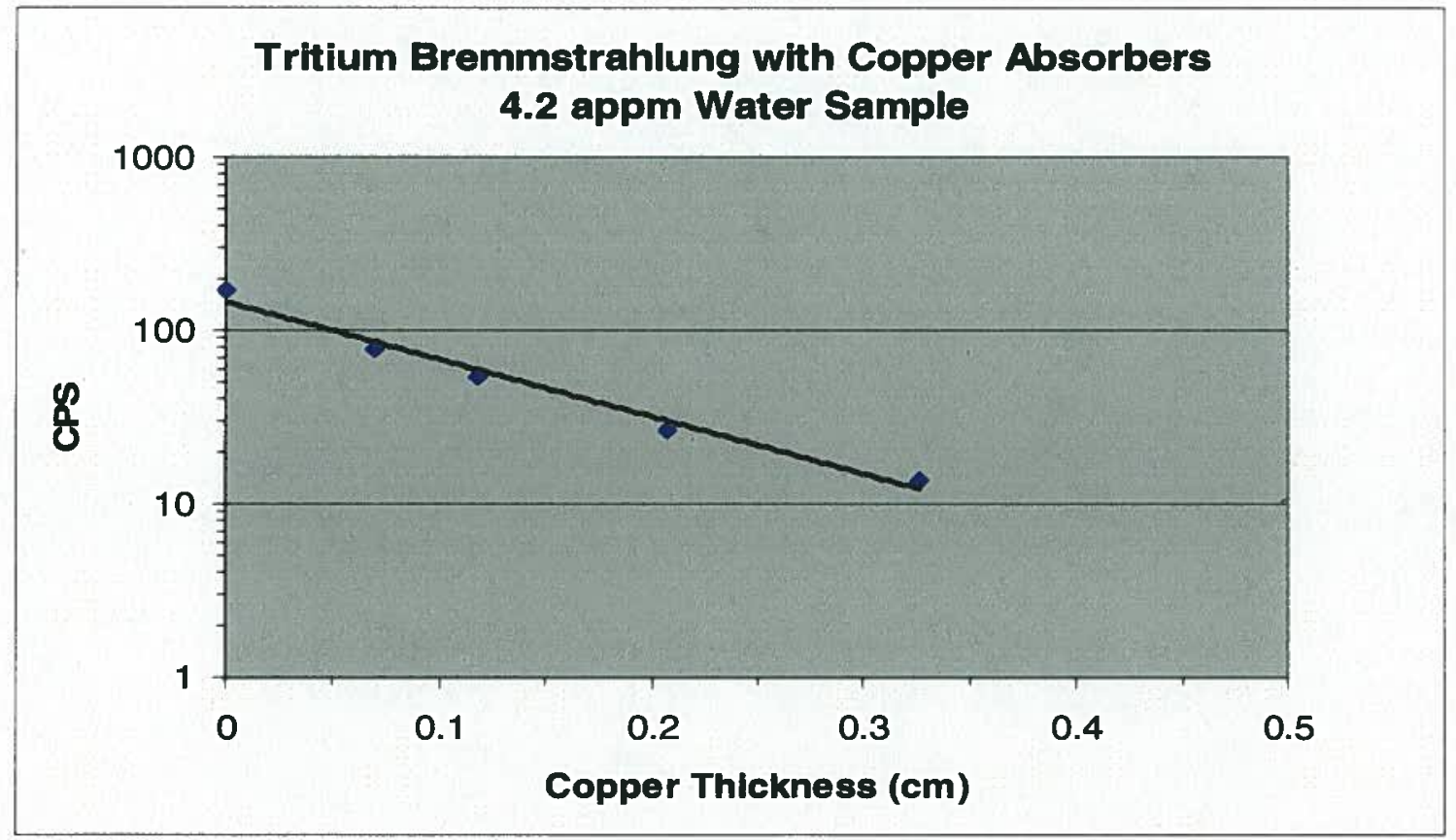

Figure 8. Changes in combined tritium Bremsstrahlung and copper $X$-ray count rates using increasing thicknesses of copper absorbers. 
The recorded data shows the production of a low energy effect that was induced by the K Xray fluorescence. Additionally, as seen in the beryllium and aluminum absorbers, a high energy peak shift was observed. These data suggest even with the measured fluorescence of copper, a stainless steel window of moderate thickness could be used for counting relatively high levels of tritium and provide quantitation of tritiated water within the range seen in the zeolite beds.

\subsection{CONCLUSION}

Implementing an appropriate on-line technology for tritium analysis and providing a tested tritiated waste form/package for disposal will help the Tritium Facility meet a recognized need, achieve significant annual cost savings, and avoid unnecessary personnel exposures and environmental contamination. The ability to measure Bremsstrahlung radiation of a tritiated process sample using a polyoxymethylene windowed cell and a NaI scintillation detector was demonstrated. With a count time as little as 0.5 minutes, the limit of detection was 24 atomic parts per billion. Additionally, a window of stainless steel of moderate thickness $(0.3 \mathrm{~cm})$ could be used for counting relatively high levels of tritium.

\subsection{REFERENCES}

[1] R. A. Sigg, D. P. DiPrete, D. J. Pak, L. M. Arrigo, "Remote Analysis of High-TritiumContent Water," WSRC-STI-2007-00417, Savannah River National Laboratory, Aiken SC.

[2] R. A. Sigg, D. P. DiPrete, D. J. Pak, L. M. Arrigo, "Remote Analysis of High-TritiumContent Water," Fusion Science and Technology 54, 167 (2008).

[3] K. E. Zeigler, L. L. Tovo, A. S. Poore, "Analytical Results of Z-Bed Recovery System Water Sample," SRNL-TR-2009-00250, Savannah River National Laboratory, Aiken SC.

[4] Email Correspondence between Louis Boone and Laura Tovo. Email dated 10/15/2008. 